\title{
Compressed Image Manipulation and Replication over Cloud
}

\author{
Pradnya Jadhav \\ Dept. of IT SAOE,
}

Kondhwa, Pune 48, India.

\author{
Pooja Desai \\ Dept. of IT SAOE, \\ Kondhwa, Pune 48, India.
}

\author{
Pranav Dharashive \\ Dept. of IT SAOE, \\ Kondhwa, Pune 48, India.
}

\author{
Shrikant Sonone \\ Dept. of IT SAOE, \\ Kondhwa, \\ Pune 48, India.
}

\author{
N.S. Sharma \\ Assistant Professor \\ Dept. of IT SAOE, \\ Kondhwa, Pune 48, India.
}

\begin{abstract}
Compression technique is used for reducing the quantity of data without compromising the quality of image. Image Compressions the solution associated with transmission and storage of large amount of information for digital storage ${ }^{[2]}$. Transmission of image includes different applications. Image Compression is used to minimize the amount of memory needed to represent an image, for storage or transmission of information ${ }^{[5]}$
\end{abstract}

\section{Keywords}

Cloud, VP8 ${ }^{[1]}$, Webp ${ }^{[1]}$, Image Processing, Computation Performance

\section{INTRODUCTION}

A single website has many full size images and compressed low resolution thumbnail images. These may be available in static files or SQL images, managing these as the number of images increases, it becomes difficult. The web designers download images from client, compress and resize them, to fit the current design as the number increases the task becomes difficult and time consuming to download images and compress them. In this project distribution of the work load to the cloud computing as it has high processing power and low latency over multitask.

\section{CONCEPTS}

\subsection{Image Compression}

Reduce the size of image without compromising the quality of image. Compression is used to minimize the amount of memory needed to represent an image, for storage or transmission of information ${ }^{[5]}$. Figure 1 shows the general compression and decompression using $\mathrm{DCT}^{[2]}$ and figure 2 shows the

\subsection{Webp Image Codec}

It is a image format to compress uploaded images on the cloud and show it over the web browser and replicate changes to the uncompressed images. This format is owned by ON2 technologies and developed by Google. This format is based on intraframe coding of $\mathrm{vp} 8{ }^{[1]}$ video format. This image format employees both lossy and lossless compression

\subsection{Manipulation}

For editing images to create illusion, manipulation is done. The enhancement in manipulation can be sharpness, noise removing elements or visible flaws on skin or material.

\subsection{Replication}

Information sharing so as to ensure consistency between the redundant resources such as hardware and software to improve reliability, fault tolerance or accessibility.

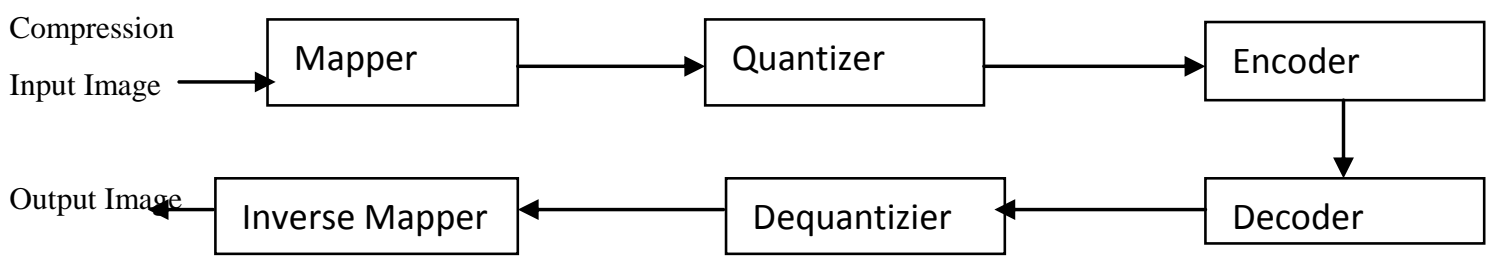

Decompression

Fig 1: General compression Decompression ${ }^{[2]}$

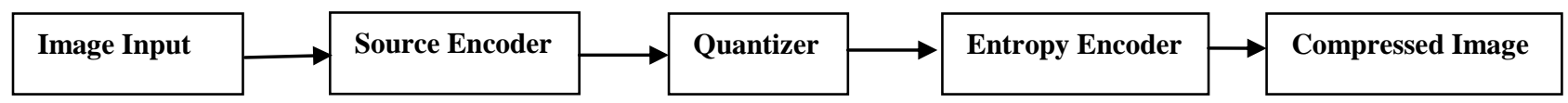

Fig 2. Lossy Compression Techniques 


\section{LITERATURE SURVEY}

\begin{tabular}{|c|c|c|c|}
\hline $\begin{array}{l}\text { Sr. } \\
\text { No }\end{array}$ & Authors & Work done & Limitations \\
\hline 1 & $\begin{array}{l}\text { Consel, C. } \\
\text { INRIA,LaBRI } \\
\text {,Talence,Fran } \\
\text { ce } \\
\text { Reveillere,L. }\end{array}$ & $\begin{array}{l}\text { Developed a platform } \\
\text { for multimedia } \\
\text { communication } \\
\text { services. } \\
\text { Client-server model ( } \\
\text { 6-10-2013) }\end{array}$ & $\begin{array}{l}\text { service- } \\
\text { description } \\
\text { language } \\
\text { should be } \\
\text { used }\end{array}$ \\
\hline 2 & $\begin{array}{l}\text { Sain,M.; } \\
\text { Dongseo } \\
\text { University, } \\
\text { Busan, South } \\
\text { Korea. }\end{array}$ & $\begin{array}{l}\text { Explore the future of } \\
\text { cloud middleware and } \\
\text { the challenges ahead } \\
\text { in cloud computing } \\
\text { Cloud Middleware } \\
(27-30-2013)\end{array}$ & $\begin{array}{l}\text { Support open } \\
\text { stacks, } \\
\text { provide } \\
\text { generic } \\
\text { interfaces } \\
\text { between } \\
\text { components. }\end{array}$ \\
\hline 3 & $\begin{array}{l}\text { Bitzer,B; } \\
\text { South } \\
\text { Westphalia } \\
\text { Univ.of } \\
\text { Appl.Sci, } \\
\text { Soest, } \\
\text { Germany; } \\
\text { Gebretsadik }\end{array}$ & $\begin{array}{l}\text { Handling of } \\
\text { monitoring of } \\
\text { renewable energy in } \\
\text { smart grid. Cloud } \\
\text { Computing } \\
\text { framework for smart } \\
\text { grid applications } \\
(02-05-2013)\end{array}$ & $\begin{array}{l}\text { Availabilities } \\
\text { of energy } \\
\text { management } \\
\text { software tools } \\
\text { in smart grid. }\end{array}$ \\
\hline 4 & $\begin{array}{l}\text { Zhang ya-mei: } \\
\text { dept of } \\
\text { comput.sci \& } \\
\text { technol,Henan } \\
\text { Mech \& Elec } \\
\text {.Engg coll. } \\
\text { XinXiang, } \\
\text { China. } \\
\text { Cen Jun-Jie }\end{array}$ & $\begin{array}{l}\text { By selecting various } \\
\text { real time tracing to } \\
\text { extend the image. } \\
\text { Adobe photoshop. } \\
\text { Method } \\
\text { transformation from } \\
\text { bitmap to vector } \\
\text { graphics based on } \\
\text { adobe illustrator CSH } \\
(20 \text { Aug 2010) }\end{array}$ & $\begin{array}{l}\text { The images } \\
\text { first need to } \\
\text { be saved in } \\
\text { PC \& then } \\
\text { open in } \\
\text { photoshop. }\end{array}$ \\
\hline 5 & $\begin{array}{l}\text { Shrikant,S. } \\
\text { ECE dept, } \\
\text { NIT Roerkela, } \\
\text { Rourkela, } \\
\text { India. } \\
\text { Meher,S. }\end{array}$ & $\begin{array}{l}\text { Combines diff. } \\
\text { embedded wavlet } \\
\text { based image coding } \\
\text { with Huffman- } \\
\text { encoder } \\
\text { Compression } \\
\text { technique using HE } \\
(03-05-2013)\end{array}$ & $\begin{array}{l}\text { Reconstructio } \\
\mathrm{n} \text { at decoder } \\
\text { with } \\
\text { additional } \\
\text { computational } \\
\text { complexity } \\
\text { provides } \\
\text { significant } \\
\text { quality }\end{array}$ \\
\hline 6 & $\begin{array}{l}\text { Bar-Ness,Y. } \\
\text { dept.of elec } \\
\text { engg.Newjers } \\
\text { ey inst. Of } \\
\text { technol, } \\
\text { Newyork } \\
\text { NJ,USA. } \\
\text { Choi,S,Politi, } \\
\text { S. }\end{array}$ & $\begin{array}{l}\text { A string dictionary } \\
\text { structure is proposed, } \\
\text { combines the } \\
\text { advantages of offering } \\
\text { possibility } \\
\text { hardware } \\
\text { implementation } \\
\text { Arithmetic Coding + } \\
\text { sliding dictionary = A } \\
\text { string dictionary } \\
\text { structure }\end{array}$ & $\begin{array}{lr}\text { Data from } \\
\text { statistical } \\
\text { unknown } \\
\text { sources is } \\
\text { difficult to } \\
\text { compress. }\end{array}$ \\
\hline
\end{tabular}

\begin{tabular}{|c|c|c|c|}
\hline & & $(12-06-1988)$ & \\
\hline 7 & $\begin{array}{l}\text { Yu shen; } \\
\text { informationiz } \\
\text { ation office , } \\
\text { Donghua } \\
\text { Univ, } \\
\text { shanghai, } \\
\text { china; Xie } \\
\text { ping Gao; } \\
\text { linlangliu; } \\
\text { Caixia li }\end{array}$ & $\begin{array}{l}\text { Approximation of } \\
\text { original data to be } \\
\text { reconstructed in } \\
\text { exchange for better } \\
\text { compression ratios } \\
\text { Approach to develop } \\
\text { integer to integer } \\
\text { multivavelets } \\
\text { (28-oct-2011) }\end{array}$ & $\begin{array}{l}\text { In lossless the } \\
\text { reconstructed } \\
\text { image is } \\
\text { similar to i/p } \\
\text { image }\end{array}$ \\
\hline
\end{tabular}

-Consel. Et.al. has done work in developing a platform for multimedia communication services. They developed a ClientServer model on $6^{\text {th }}$ October 2013. The service description language should be used in this model which is its limitation.

-Sain, M.; Dongseo University; Busan, South Korea.had done work in exploring the future of cloud middleware, challenges in cloud computing. The limitation in this model is that it can support open stacks, provide generic interfaces between components.

- Bitzer, B; South Westphalia University of Application Science, Soest, Germany; Gebrestsadik done work in handling of monitoring of renewable energy in smart grid. Cloud computing framework for smart grid applications. Limitations for this model are the availabilities of energy management software tools in smart grid.

-Zhangya-Mei department of computer science technology, Henan Mechanical and Electrical Engineering College. Xinxiang, China. Cen Jun-Jie. Worked on various real times tracing to extend the image, the disadvantage is that images first need to be saved in the pc and them open in Photoshop.

- Shrikant, S. ECE department, NIT Roerkela, Rourkela, India. Meher, $\mathrm{S}$ worked in Combines diff. embedded wavelet based image coding with Huffman-encoder Compression technique using HE. The disadvantage is Reconstruction at decoder with additional computational complexity provides significant quality

-Bar-Ness.Y. Department of electronic engineering. New jersey inst. Of technol, Newyork NJ, USA. Choi, S, Poloto, S. worked on a string dictionary structure is proposed, combines the advantage of offering possibility of hardware implementation. The disadvantage is that the data from the statistical unknown sources is difficult to compress.

-Yu shen; informationization office, Donghua Unvi. Shanghai, China; Xie ping Gao; Linlangliu Caixia li worked for approximation of original data to be reconstructed in exchange for the better compression ratios. Approach to develop integer to integer multivavelets. The limitation is in lossless the reconstructed image is similar to the input image.

\section{PROBLEM IDENTIFIED}

From the existing literature survey there has been problems identified which are stated below:

From [1] the problem identified: is $v p 8^{[1]}$ can make best use of computation power in modern hardware for improving compression efficiency and maintaining fast decoding speed on majority devices connected to the web

There is great potential for innovation in future version of $\mathrm{vp} 8^{[1]}$ encoder and decoder 
From [2] the problems identified: is the need of lossless compression, its principles, benefits, performance measures and various techniques of lossless compression

From [3] following are the problems identified: Compression algorithm depends upon 3 factors:

$$
\begin{aligned}
& \text { 1. Quality of image } \\
& \text { 2. Amount of compression } \\
& \text { 3. Speed of compression }
\end{aligned}
$$

Existing system is time consuming, large data is required and continuous uploading and downloading is carried. Higher cost is required. And high resource value. Hence to propose the system named "CIMAROC"

\section{SOLUTION PROPOSED}

To minimize the time and developers task, to lower all the optimization load, moving towards to a solution that using various compression techniques to compress images from the cloud and download it to browser and replicate the changes to the uncompressed images. This will minimize the post uploaded changes.

\subsection{Diagrams of Output}

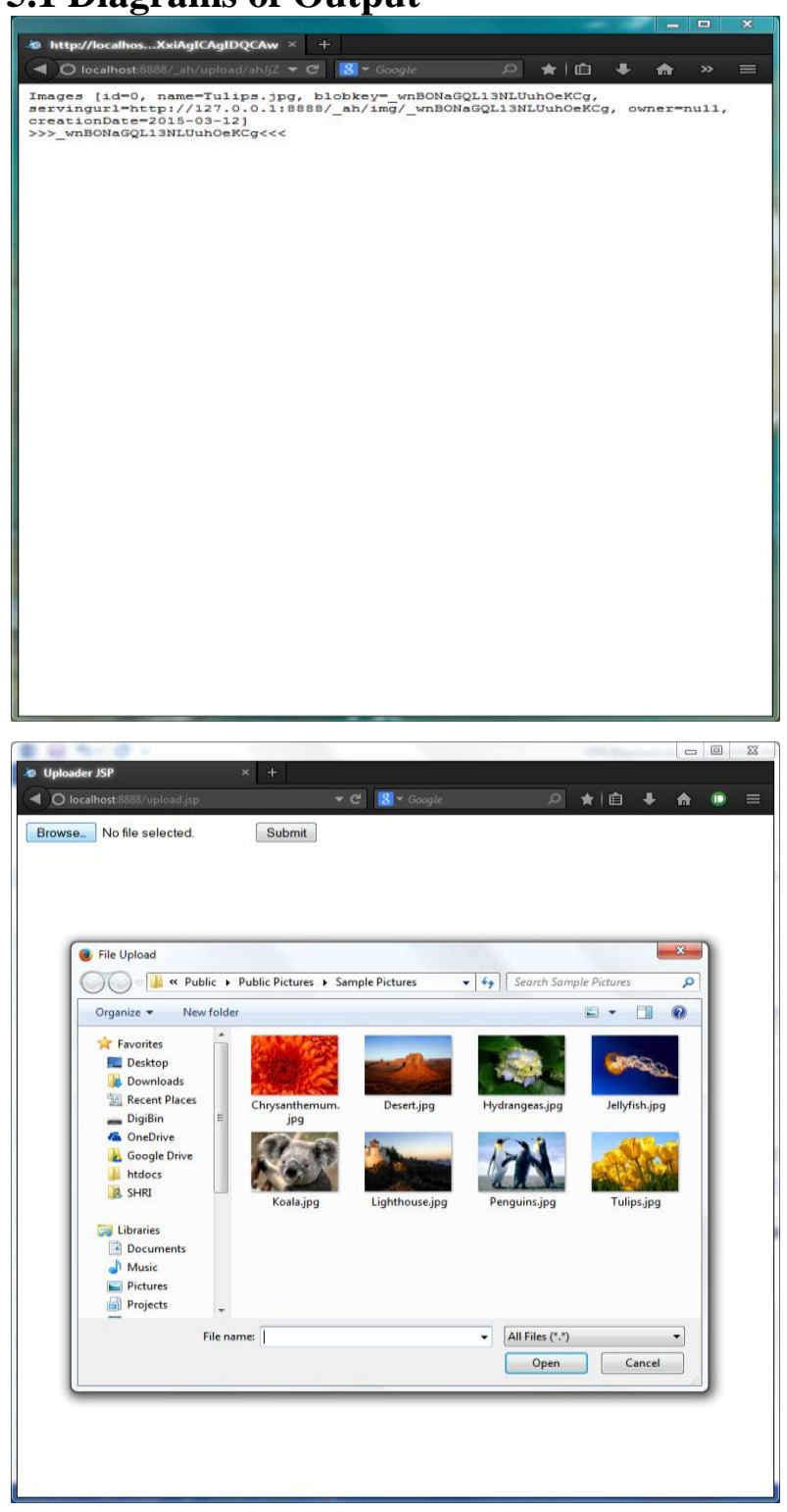

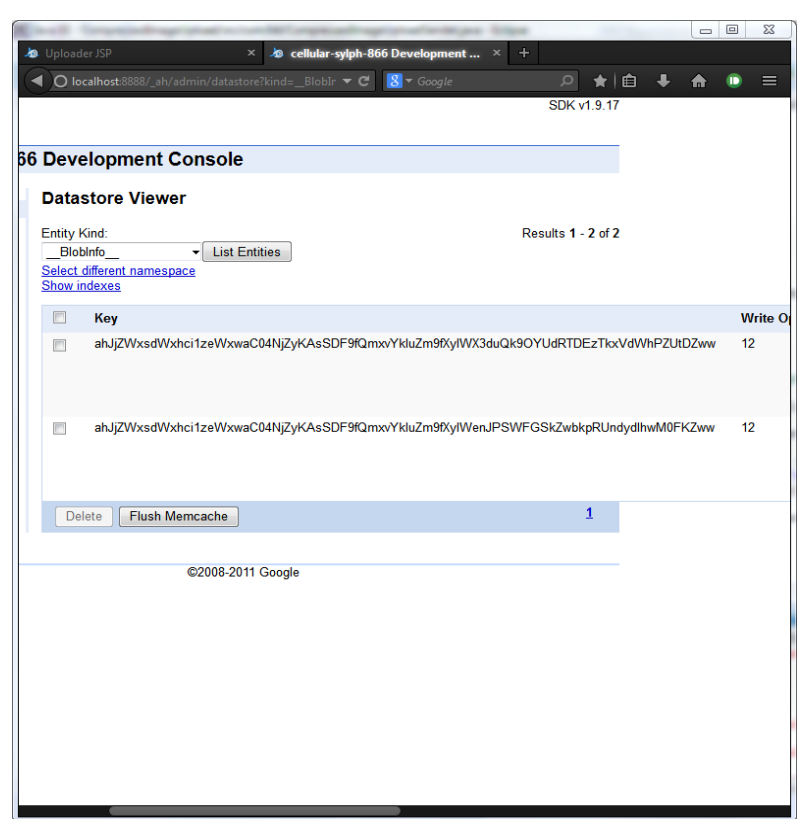

\section{CONCLUSION}

This project reduces developers and company load to convert and optimize images in shared way. Company assests can be used for other tasks which will make output more productive.

\section{REFERENCES}

[1] Jim Bankoski, Paul Wilkins, Yaowu Xu, "TECHNICAL OVERVIEW OF VP8, AN OPEN SOURCE VIDEO CODEC FOR THE WEB", Google Inc. 1600 Amphitheatre Parkway, Mountain View, CA, USA.

[2] Mr. Chandresh K. Parmar, Prof. Kruti Pancholi, "A REVIEW ON IMAGE COMPRESSION TECHNIQ,UES”, ISSN: 0975 - 6736, Department of Electronics and Communication L.J. Institute of Engineering and Technology ,GTU Ahmedabad, Gujrat, India.

[3] Francesca De Simone, Lutz Goldmann, Jong-Seok Lee, and Touradj Ebrahimi Ecole Polytechnique Federale de Lausanne (EPFL), Lausanne, Switzerland, "PERFORMANCE ANALYSIS OF VP8 IMAGE AND VIDEO COMPRESSION BASED ON SUBJECTIVE EVALUATIONS", Swiss National Foundation for Scientific Research in the framework of NCCR Interactive Multimodal Information Management (IM2)

[4] Wie-Yi Wei "AN INTRODUCTION TO IMAGE COMPRESSION" Graduate institute of Communication Engineering, National Taiwan University, Taipei, Taiwan, ROC

[5] Aarti, "A REVIEW ON LOSSLESS IMAGE COMPRESSION TECHNIQUES”, Department of CSE, ACET, India.

\section{AUTHOR'S PROFILE}

Pradnya Jadhav was born in Ahmednagar on $22^{\text {nd }}$ of June 1993. She has completed her SSC studies form Sacred Heart Convent School, Ahmednagar in 2008 \& secured $77.77 \%$. After completing SSC she completed HSC from BPHE's Society Ahmednagar College, Ahmednagar in 2011 \& secured $71 \%$ currently she is pursuing Bachelors Degree in Information Technology from SAOE., Kondhwa Pune and it will complete in June 2015. 
Shrikant Sonone was born in Akola on $31^{\text {st }}$ of March 1991. $\mathrm{He}$ has completed his SSC studies form Jagruti Vidyalaya Akola, in 2006 \& secured $59 \%$ after completing SSC he completed HSC from Jagruti Junior college, Akola, in 2008 \& secured $66 \%$. Currently $\mathrm{He}$ is pursuing Bachelor's degree in Information Technology from S.A.O.E., Kondhwa Pune and it will complete in June 2015.

Pranav Dharashive was born in on $1^{\text {st }}$ of May 1991. He has completed his SSC studies form Keshav Raj High school, latur, in 2006 \& secured $63.3 \%$ after completing SSC he completed HSC from Chandrabhanu Sonawane College, Latur, in 2008 \& secured $60 \%$. Currently he is pursuing Bachelors Degree in Information Technology from SAOE., Kondhwa Pune and it will complete in June 2015.
Pooja Desai was born in Lasalgaon on $1^{\text {st }}$ of October 1990. She has completed her SSC studies form Jijamata Kanya Vidyalay, Lasalgaon in 2008 \& secured $70 \%$. After completing SSC she completed Diploma from K.B.P.Polytechnic, Kopergaon, in 2011 \& secured $83.56 \%$. Currently she is pursuing Bachelors Degree in Information Technology from SAOE., Kondhwa Pune and it will complete in June 2015.

N.S. Sharma has completed His bachelors of egg. Degree in Information Technology from Bharti Vidyapeeth Pune University. After Bachelors Degree in IT, he completed ME from Thapur University Patiyala Currently he is Asst. Prof. In SAOE, IT department, Pune. 